\title{
Adverse influence of $\beta$-methylcholanthrene on detoxification function of chick embryo brain glutathione S-transferases and degenerative changes of brain
}

\author{
Sreenivasulu Dasari", Sailaja Gonuguntla, Balaji Meriga, Thyagaraju Kedam \\ Department of Biochemistry, Sri Venkateswara University, Tirupati-517502, Andhra Pradesh, India.
}

\section{ARTICLE INFO \\ Article history: \\ Received on: 18/11/2017 \\ Accepted on: 06/02/2018 \\ Available online: 30/03/2018

\author{
Key words: \\ $\beta$-methylcholanthrene, \\ chick embryo, glutathione \\ S-transferses, western blot, \\ brain degeneration.
}

\begin{tabular}{l}
\hline ABSTRACT \\
\hline$\beta$-methylcholanthrene $(\mathrm{MC})$ is a potent toxic agent that related to polycyclic aromatic hydrocarbons and its adverse \\
influence on detoxification function of chick embryo brain glutathione S-transferases (GSTs) and brain degenerative \\
changes was investigated. MC $(2 \mathrm{ppm} / 10 \mu \mathrm{l})$ was injected in coconut oil up to $6 \mathrm{ppm}$ though air sac on $15^{\text {th }}$ day \\
for 24 hours interval and $12^{\text {th }}$ day for 48 hours interval. Brain tissues were collected on $18^{\text {th }}$ day post injection for \\
experimentation. Results revealed that GST specific activity has increased significantly $(\mathrm{p}<0.05)$ with model \\
substrates by $2 \mathrm{ppm}$ and $4 \mathrm{ppm}$ MC in both intervals, but decreased significantly $(\mathrm{p}<0.05)$ by 6 ppm in both intervals \\
and western blot studies also shows similar pattern of GST expression. At histological level that the cerebellar layers \\
degeneration, molecular layer expansion towards granular layer and vacuolation were observed in 24 hours interval, \\
but severe cerebral haemorrhage and vacuolation were observed in 48 hours interval by 6 ppm MC. In conclusion, MC \\
showed adverse influence on GSTs function and brain degeneration in chick embryo.
\end{tabular}

\section{INTRODUCTION}

Glutathione S-transferase (GST: EC 2.5.1.18) is an enzyme that can detoxify reactive metabolites like drugs and environmental chemicals, so that GST is regarded as toxicologically crucial enzymes (Arakawa et al., 2013). GSTs are exhibiting multiple reactions with a multitude of endogenous and exogenous substrates (Salinas and Wong, 1999). GST super gene family is an important cellular defence enzyme against endogenous and exogenous toxic chemical compounds; some of them have carcinogenic potential (Ates et al., 1995; Strange and Fryer, 1999). GSTs are contributing in the phase II biotransformation of xenobiotics and carcinogens (Voso et al., 2008). In a review, Hayes and Pulford (1995) said that the GSTs are evolved to protect cell against reactive oxygen metabolites. Li et al. (2013) observed that

\footnotetext{
${ }^{*}$ Corresponding Author

Sreenivasulu Dasari, Postdoctoral Fellow, Department of Biochemistry, Sri Venkateswara University, Tirupati-517502, Andhra Pradesh, India. E-mail: dasarisreenivaasulu@gmail.com
}

the GST isoforms concrete relationship with oxidative stress. GST is an oxidative stress marker, it may play protective role when free radicals are produced (Acharjee and Mahanta, 2014). GSTs can detoxify wide range hazardous substances by transferase activity and GST associated peroxidase activity (Dasari et al., 2017a). The presence of GST activity in wild birds appeared in 1968. Usually, birds are extremely mobile; it is difficult to exclude them from polluted areas. They eat contaminated food and drink contaminated water by the agricultural chemical formulas, industrial chemical pollutants etc. In birds, the GSTs which play key role to detoxify toxic agents, they act as biomarker to assess the health condition of birds (Dasari et al., 2017b). These chemical pollutants show direct effect on brain. Chick embryo brain GST $\left(\mathrm{CB}_{\mathrm{I}} \& \mathrm{CB}_{\mathrm{II}}\right)$ protein biomarkers can protect the developing brain from environmental toxic chemical agents (Dasari et al., 2017c).

$\beta$-methylcholanthrene (MC) is one of the polycyclic aromatic hydrocarbon, experimental tumour promoting carcinogenic agent in biochemical research. Throughout the world, the urban environments are filled with PAH mainly by fossil fuel combustion (Perera et al., 2014). Heating systems, vehicle motors 
and the inadequate combustion of solid and fuel oils are usually the common sources of $\mathrm{PAH}$, which consider as main reason for air pollution (O'Donnell et al., 2006). Carcinogenic, mutagenic and immunosuppressive effects of PAHs are well established (Armstrong et al., 2004). PAHs are light sensitive, resistance to heat, corrosion resistance and many exhibit physiological actions (Akyuz and Cabuk, 2010). PAHs are used as intermediaries in pharmaceuticals, agricultural products, photographic products, thermosetting plastics, lubricating materials and many other chemical products (Kaminski et al., 2008). PAHs are composed of two or more benzene rings bonded as linear, cluster or angular arrangements (Di Toro et al., 2000). Usually vegetable oils are contaminated by PAHs during technological processes that are direct fire drying, in connection to this that the combustion products come into contact with the oil seeds including oil (Speer et al., 1990). Lannerö et al. (2008) said that the tobacco smoke contains more than forty PAHs which are known or suspected carcinogens. PAHs are un-metabolized toxic compounds; some of them can bind to cellular proteins and DNA (Armstrong et al., 2004). Whatever concentrations of drugs and chemicals are usually safe to well-developed brain are more vulnerable to the developing brain (Bal-Price et al., 2010). Tilson (2000) was suggested that the non-availability of blood brain barrier (BBB) in the developing brain is one of the reasons for easy susceptibility to drugs and chemicals. That the lipophilic nature of PAH facilitate to cross placenta as well as immature blood brain barrier (BBB) and thereby target the developing brain (Liu et al., 2011; Nielsen et al., 2011). PAHs are interacting with brain tissues (Tayebati et al., 2009).

The exposure of PAHs to developing brain is very common in case of maternal cigarette smoking during pregnancy (Rodgman et al., 2000; Polanska et al., 2009). It was studied that the maternal cigarette smoking as well as alcohol consumption during pregnancy causes poor intelligence quotient (Batty et al., 2006), behavioural problems (Thapar et al., 2003) and psychiatric disorders (Grandjean and Landrigan, 2006) in offspring. Singh et al. (2013) was concluded that at early stage of neuronal development is metabolically very active than mature cells but more susceptible to $\mathrm{PAH}$, so that MC may impair developing brain function. That the aryl hydrocarbon receptor (AHR) is the crucial mediator of $\mathrm{MC}$ toxicity which translocate from cytoplasm into nucleus (Omiecinski et al., 2010). The present study was aimed to evaluate the adverse influence of $\beta$-methylcholanthrene (MC) on detoxification function of chick embryo brain glutathione S-transferases including degenerative changes in developing brain.

\section{MATERIALS AND METHODS}

\section{Chemicals}

Reduced glutathione (GSH), acrylamide (AC) 99.9\%, N,N-methylene-bis-acrylamide, $\quad \beta$-mercaaptoethanol, 1-chloro 2,4-dinitro benzene (CDNB), Bromosulfopthalein (BSP), p Nitrobenzyl chloride (p-NBC), 1,2-Epoxy 3(p-nitro penoxy propane (EPNP), p-Nitrophenyl acetate (p-NPA), were purchased from SRL Pvt Ltd. Mumbai, India and Bio-Rad laboratories (Richmond, USA). $\beta$-methylcholanthrene (MC) was purchased from Sigma Chemical Company, St. Louis, MO,
USA. 5-bromo-4-chloro-3-indolyl phosphate (BCIP), Nitroblue tetrazolium (NBT), Ponseau-S stain, Freund's incomplete and complete adjuvants were purchased from Bio-Rad laboratories, Richmond, USA and Genei, Banglore, India. Goat anti rabbit IgG antibodies (Bio-Rad laboratories, Richmond, USA) and Nitrocellulose (NC) membrane (Amerssham, UK) were gifted by my friend Reddy Peera, National Brain Research Center (NBRC), Gurgaon, Haryana, India. Hydroxymethyl aminomethaane (Tris base), Ammonium persulphate (APS), Ethylenediaminetetraacetic acid (EDTA), Phenylmethanesulphonyl fluoride (PMSF), Sodium azide, Sodium potassium tartrate, Sodium chloride (NaCL), Potassium chloride (KCL), Cumene hydroperoxide (CHP), skim milk powder and all required chemicals were purchased from the local chemical companies with high quality. Haematoxylin and Eosin were purchased from BDH Chemicals Company, Mumbai, India.

\section{Maintenance of eggs and route of chemical administration}

Fertilized Babcock strain chicken eggs were obtained from poultry department, Sri Venkateswara Veterinary University, Tirupati. Eggs weighing about 50 grams were allowed for incubation at $37^{\circ} \mathrm{C}$, maintained $60 \%$ humidity in incubator, and rotated them daily twice. For chemical administration, a hole was made at the blunt end of the egg on the shell where chemical was injected with a micro syringe though air sac. The inner shell membrane of egg is in direct contact with chorio-allantoic membrane. Therefore this route of administration allowed faster uptake of the chemical substance than yolk injections. During this process the survival embryos were tested using candler light. The dead eggs were discarded and survived eggs were selected for the experiments.

\section{Administration schedule of MC}

24 hours interval: On fifteenth day embryos were treated with $\mathrm{MC}$ in coconut oil through air sac for three days with an interval of 24 hours to a total concentration of $6 \mathrm{ppm}$ at rate of $2 \mathrm{ppm}$ per $10 \mu \mathrm{l}$ of each dose. Control embryos were maintained by vehicle only.

48 hours interval: On twelfth day embryos were treated with $\mathrm{MC}$ in coconut oil through air sac for three days with an interval of 48 hours to a total concentration of $6 \mathrm{ppm}$ at rate of 2 ppm per $10 \mu \mathrm{l}$ of each dose. Control embryos were maintained by vehicle only.

\section{Tissue collection and sample preparation}

On $18^{\text {th }}$ day, control and MC treated embryos were collected and brain tissue was collected by pressing small head with forceps, washed them with cold $50 \mathrm{mM}$ Tris HCL buffer ( $\mathrm{pH}$ 8.0) containing $1 \mathrm{mM}$ EDTA, to remove excess blood and body fluids, some of collected tissue was immediately fixed for histological study and remaining tissues was preserved at $-20^{\circ} \mathrm{C}$ for further experimentation.

Brain tissues were slightly thawed, minced with scissors and then prepared twenty per cent homogenate with $50 \mathrm{mM}$ Tris HCL buffer ( $\mathrm{pH}$ 8.0) containing $0.25 \mathrm{M}$ sucrose and PMSF by using potter Elvijhem homogenizer which is already in an ice jacket. The homogenate was subjected to filter through cheese cloth in order to remove floating lipid materials. The resultant 
homogenate was then centrifuged at $4^{\circ} \mathrm{C}$ two times by 45 minutes at $10,000 \mathrm{rpm}$. The resultant supernatant was known as cytosolic GSTs fraction and it was used for GST activity and specific activity assays. Usually, fresh tissues were used for all assays.

\section{GST activity assay}

Brain GST activity was assayed by the method of Habig et al. (1974). The reaction mixture consists $1 \mathrm{ml}$ of $0.3 \mathrm{M}$ phosphate buffer (pH 6.5), $30 \mathrm{mM} \mathrm{CDNB} 100 \mu 1,30 \mathrm{mM}$ GSH $100 \mu \mathrm{l}$ and enzyme $100 \mu \mathrm{l}$. This reaction mixture was made up to $3 \mathrm{ml}$ with distilled water. An increase in absorbance was measured at $340 \mathrm{~nm}$ by using spectrophotometer. One unit of GST activity was defined either as formation one $\mu$ mole of 2,4 dinitrophenol-glutathione conjugate per minute or one $\mu$ mole of substrate consumed per minute.

\section{Specific activity studies}

Specific activity assays were carried out by the method of Jacoby and Habig (1980) and Wendel (1981) to screen the GST isoenzymes, which expressed by the administration (MC), with model substrates such as 1-chloro 2,4-dinitro benzene (CDNB), Bromosulfopthalein (BSP), p Nitrobenzyl chloride (pNBC), 1,2Epoxy 3(p-nitro penoxy propane (EPNP), p-Nitrophenyl acetate (pNPA) and Cumene hydroperoxide (CHP). Summary of GST specific activity studies procedures were showed in Table 1.

Table 1: GST specific activity studies procedures summary.

\begin{tabular}{|c|c|c|c|c|c|}
\hline Substrate & Contents of reaction mixture & Molar Extinction coefficient $\left(\mathrm{cm}^{-1}\right)$ & Absorbance & Initiator & Method \\
\hline CDNB & $\begin{array}{c}1 \mathrm{ml} \text { of } 0.3 \mathrm{M} \text { phosphate buffer (pH 6.5), } 30 \mathrm{mM} \text { CDNB } 100 \mu \mathrm{l} \text {, } \\
\text { Enzyme } 100 \mu \mathrm{l} \text {, Total Vol } 3 \mathrm{ml}\end{array}$ & $9.6 \times 10^{3}$ & $340 \lambda$ & 30 mM GSH $100 \mu \mathrm{l}$ & \\
\hline BSP & $\begin{array}{c}1 \mathrm{ml} 125 \mathrm{mM} \text {, phosphate buffer (pH 6.5), } 1 \mathrm{mM} \text { BSP } 100 \mu \mathrm{l} \text {, } \\
\text { Enzyme: } 200 \mu \mathrm{g} \text {, Total vol } 3 \mathrm{ml}\end{array}$ & $4.5 \times 10^{3}$ & $330 \lambda$ & $5 \mathrm{mM}$ GSH $100 \mu \mathrm{l}$ & \\
\hline $\mathrm{pNBC}$ & $\begin{array}{c}1 \mathrm{ml} 100 \mathrm{mM} \text { phosphate buffer (pH 6.5), } 1 \mathrm{mM} \text { pNBC } 100 \mu \mathrm{l} \text {, } \\
\text { Enzyme } 200 \mu \mathrm{g} \text {, Total Vol. } 3 \mathrm{ml}\end{array}$ & $1.9 \times 10^{3}$ & $310 \lambda$ & $5 \mathrm{mM}$ GSH $100 \mu \mathrm{l}$ & $\begin{array}{l}\text { Jacoby \& Habig } \\
\text { (1981) }\end{array}$ \\
\hline pNPA & $\begin{array}{c}1 \mathrm{ml} 125 \mathrm{mM} \text { phosphate buffer (pH 7.0), } 0.3 \mathrm{mM} \text { pNPA } 100 \mu \mathrm{l} \text {, } \\
\text { Enzme: } 200 \mu \mathrm{g} \text {, Total Vol. } 3 \mathrm{ml}\end{array}$ & $8.79 \times 10^{3}$ & $400 \lambda$ & $0.5 \mathrm{mM}$ GSH $100 \mu \mathrm{l}$ & \\
\hline EPNP & $\begin{array}{c}1 \mathrm{ml} 125 \mathrm{mM} \text { phosphate buffer (pH 6.5), } 1 \mathrm{mM} \text { EPNP } 100 \mu \mathrm{l} \text {, } \\
\text { Enzyme: } 200 \mu \mathrm{g} \text {, Total Vol. } 3 \mathrm{ml}\end{array}$ & $0.5 \times 10^{3}$ & $360 \lambda$ & $\begin{array}{l}5 \mathrm{mM} \mathrm{GSH} \\
100 \mu \mathrm{l}\end{array}$ & \\
\hline CHP & $\begin{array}{c}1.8 \mathrm{ml} \text { assay buffer }\left(50 \mathrm{mM} \mathrm{Na}_{2} \mathrm{PO}_{4}(\mathrm{pH} 7), 2.5 \mathrm{mM} \text { EDTA, } 2.5\right. \\
\mathrm{mM} \text { NADPH), } 5 \mathrm{mM} \text { GSH } 100 \mu 1 \& 100 \mu \mathrm{l} \mathrm{GR} \text {, Enzyme } 250 \mu \mathrm{g}, \\
\text { Total Vol. } 3 \mathrm{ml}\end{array}$ & $6.32 \times 10^{3}$ & $340 \lambda$ & $1.2 \mathrm{mM} 100 \mu \mathrm{l} \mathrm{CHP}$ & Wendel (1981) \\
\hline
\end{tabular}

\section{Estimation of protein}

Protein concentration was determined in both control and treated cytosolic fractions as well as in affinity purified GST sample by the method of Lowry et al. (1951).

\section{Antisera production}

That the affinity purified GST protein was used for immunization of Rabbits (Newzealand White Male, 3 months old) to produce antibodies after SDS PAGE analysis as described by Laemmli (1970). Rabbit was obtained from Dept. of physiology, Sri Venkateswara Veterinary University, Tirupati. Blood was collected from rabbit and serum was stored as control for further analysis. That the rabbit hair was removed at 4-6 sites and then $1 \mathrm{ml}$ of $200 \mathrm{mg}$ of affinity purified GST protein was emulsified with an equal volume of Freund's complete adjuvant and that emulsified mixture was injected subcutaneously to the rabbit at 4 to 6 sites. The booster doses were given with an interval of a week for about four to five times. Titer of antibodies was tested before the fifth dose of immunization. The last dose was given with an incomplete adjuvant. One week after the last injection, the rabbit was bled and the serum was centrifuged at $6,000 \mathrm{rpm}$ by Remi centrifuge for 30 minutes at $4^{\circ} \mathrm{C}$ and that the collected supernatant was considered as antisera of chick embryos brain GSTs.

\section{Electro-blotting}

According to Towbin et al. (1979), electro-blotting was carried out by using Mini Blot Module (Vertical Gel System-EC
120, USA) and Nitro cellulose (NC) membrane. SDS-PAGE gel was placed for $30 \mathrm{~min}$ in Towbin buffer i.e. $25 \mathrm{mM}$ Tris HCL (pH 8.8), $192 \mathrm{mM}$ glycine and 20\% methanol. The NC membrane was washed several times with distilled water and then with Towbin transfer buffer until it was equilibrated and precaution was taken that the membrane should not become dry. The blotting stack was assembled on the top of stainless steel grid cathode located in the trough of the frame stand of the Mini Blot Module, to which a small amount of transfer buffer was added.

After the assembly, and then filled with the transfer buffer (about 2.5 Lit). The red lead was connected to the anode and the black lead to the cathode, and the proteins transfer was allowed to move anions to the direction of anode. The transfer process was performed at $4^{\circ} \mathrm{C}$ for overnight using a constant voltage of $35 \mathrm{~V}$. The $\mathrm{NC}$ membrane was removed and placed in the Ponceau-S stain to check the transferred of protein bands.

\section{Immunostaining of NC membrane}

Immunostaining was carried out according to the instruction manual provided with the goat anti-rabbit IgG secondary antibodies and all of the incubations were performed in a minimum of $5 \mathrm{ml}$ of solutions in each step with continuous shaking at room temperature.

The electro-blotted NC membrane was incubated in the blocking solution ( $5 \%$ non-fat dry milk powder) in transfer buffer saline (TBS) for 30 minutes. After that, the NC membrane was incubated with chick embryo brain anti GST primary antibodies (1:2000 dilutions) in the blocking solution for 30 minutes. After 
hybridization with primary anti bodies, NC membrane was then washed five times with TBS (5 min each) and incubated with the secondary antibody (goat anti rabbit IgG-ALP conjugate) with the 1:5000 dilution in TBS for 5 hours. After that the membrane was washed three times ( 5 min each) with TBS and then the ALP conjugate color developing solution (BCIP/NBT) was added. The specific protein bands started to appear after 10-30 min. Finally, the membranes were carefully dried and the images were obtained by using a scanner connected to the computer.

\section{Histopathological studies}

According to Humason (1972), brain tissue histological examination was carried out. Brain tissues were collected from both control and treated embryos and washed them gently with physiological saline i.e. $0.9 \% \mathrm{NaCl}$, in order to remove blood and fat debris adheres to them. The tissues were allowed for fixation in $10 \%$ formalin until processing and then the tissues were washed under running tap water to remove the fixative. After dehydration of tissue by a graded series of alcohol the tissues allowed clear by using methyl benzoate and subjected to embed in paraffin wax. The tissue sections were cut with $6 \mu$ thickness and then allowed for staining with haematoxylin and eosin (H \& E). That the sections were mounted with Canada balsam, after complete dehydration and clear. Finally, the sections were observed under light microscope.

\section{Statistical analysis}

That all the data which related to this study and documented results were calculated from three experiments and presented as the mean \pm standard deviation (SD). Student t-test was used in this study to identify the MC administered brain samples differed from the mean for the respective vehicle controls. That the differences between an experimental groups at the level of $p<0.05$ were regarded as significant

\section{RESULTS AND DISCUSSION}

\section{Adverse effect of MC on brain GSTs}

As shown in Table 2 and Figure $1 \mathrm{~A} \& 1 \mathrm{~B}, \mathrm{MC}$ treated brain sample by 24 hours interval, with the substrate CDNB, GST specific activity was increased to 2.7 fold and 4.49 fold in response to $2 \mathrm{ppm}$ and $4 \mathrm{ppm} \mathrm{MC}$ respectively, but decreased to 2.53 fold in response to $6 \mathrm{ppm} \mathrm{MC}$ than 4.25 fold of control. With the substrates BSP and pNBC, GST specific activities were increased to 1.52 fold $\& 1.15$ fold as well as 2.5 fold and 2.19 fold in response to $2 \mathrm{ppm}$ and $4 \mathrm{ppm} \mathrm{MC}$, respectively, but decreased to 1.42 fold and 0.64 fold, in response to $6 \mathrm{ppm} \mathrm{MC}$, respectively, than 2.13 fold and 1.55 fold of control, respectively. With the substrate EPNP, GST specific activity was increased to 1.26 fold and 2.51 fold in response $2 \mathrm{ppm}$ and 4 ppm MC, respectively, but decreased to 0.56 fold in response to $6 \mathrm{ppm} \mathrm{MC}$ than 1.45 fold of control. With the substrate p-NPA, GST specific activity was increased to 2.6 fold and 4.56 fold in response to $2 \mathrm{ppm}$ and $4 \mathrm{ppm} \mathrm{MC}$, but decreased to 2.13 fold in response to $6 \mathrm{ppm} \mathrm{MC}$ than 3.25 fold of control. With the substrate CHP, GST specific activity was increased to 1.01 fold and 1.46 fold in response to $2 \mathrm{ppm}$ and $4 \mathrm{ppm} \mathrm{MC}$, respectively, but decreased to 1.29 fold in response to $6 \mathrm{ppm} \mathrm{MC}$ than 2.3 fold of control.
Table 2: Effect of MC on chick embryo brain GSTs by 24 hours interval.

\begin{tabular}{ccccc}
\hline M. S & Control & $\mathbf{2} \mathbf{~ p p m}$ & $\mathbf{4} \mathbf{~ p p m}$ & $\mathbf{6} \mathbf{~ p p m}$ \\
\hline CDNB & $0.425 \pm 0.012$ & $0.695^{\mathrm{a}} \pm 0.023$ & $0.874^{\mathrm{a}} \pm 0.027$ & $0.172^{\mathrm{a}} \pm 0.009$ \\
BSP & $0.213 \pm 0.015$ & $0.365^{\mathrm{a}} \pm 0.021$ & $0.463^{\mathrm{a}} \pm 0.032$ & $0.017^{\mathrm{a}} \pm 0.013$ \\
pNBC & $0.155 \pm 0.014$ & $0.270^{\mathrm{a}} \pm 0.019$ & $0.374^{\mathrm{a}} \pm 0.024$ & $0.091^{\mathrm{a}} \pm 0.0011$ \\
EPNP & $0.145 \pm 0.015$ & $0.271^{\mathrm{a}} \pm 0.021$ & $0.396^{\mathrm{a}} \pm 0.029$ & $0.089^{\mathrm{a}} \pm 0.016$ \\
PNPA & $0.325 \pm 0.017$ & $0.585^{\mathrm{a}} \pm 0.026$ & $0.781^{\mathrm{a}} \pm 0.031$ & $0.112^{\mathrm{a}} \pm 0.015$ \\
CHP & $0.230 \pm 0.013$ & $0.331^{\mathrm{a}} \pm 0.023$ & $0.376^{\mathrm{a}} \pm 0.027$ & $0.101^{\mathrm{a}} \pm 0.014$ \\
\hline
\end{tabular}

The documented values are average of three separate experiments of three samples. Mean \pm standard deviation (SD). Student test $(\mathrm{a}=\mathrm{p}<0.05$ is regarded as significant specific activity of GST). Doubling the dose $2 \mathrm{ppm}$ MC per day for chick embryos by 24 hours interval. 1 unit of GST activity is defined as $1 \mu$ mole of GSH conjugate formed $/ \mathrm{min} / \mathrm{mg}$ protein (CDNB, BSP, pNBC, EPNP, pNPA), $1 \mathrm{n}$ mole of NADPH oxidised/min/mg protein (CHP).
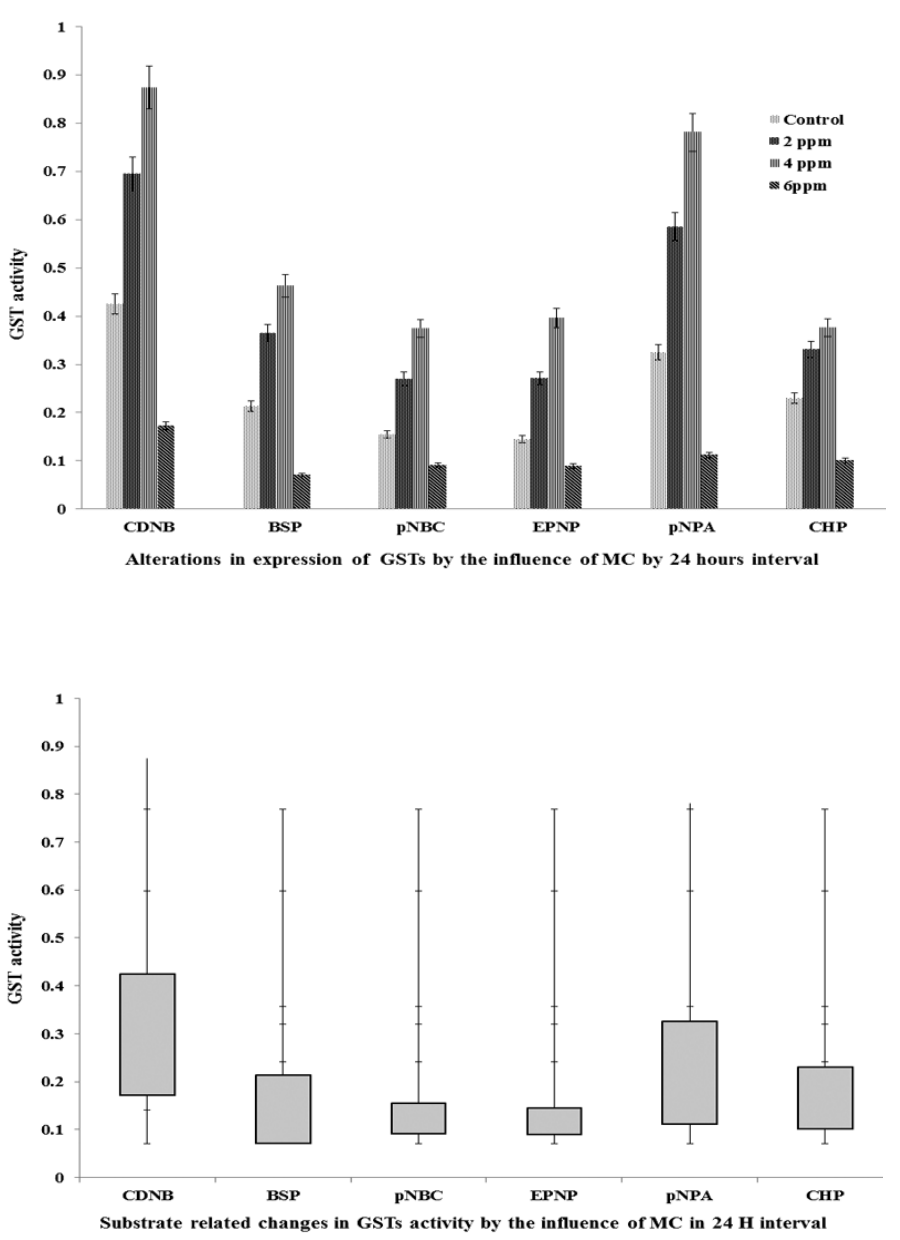

Fig. 1: (A) Expression levels of brain GSTs in response to MC by 24 hours interval. (B) MC administered brain GSTs specific activity with model substrates by 24 hours interval.

As shown in Table 3 and Figure 2A \& 2B, MC treated brain sample by 48 hours interval, with the substrate CDNB, GSTs specific activity was increased to 1.59 fold and 2.89 fold in response to $2 \mathrm{ppm}$ and $4 \mathrm{ppm} \mathrm{MC}$, respectively, but decreased 
to 4.62 fold in response to $6 \mathrm{ppm}$ MC than 6.56 fold of control. With the substrates BSP and p-NBC, GST specific activities were increased to 1.66 fold \& 1.15 fold as well as 3.73 fold and 2.07 fold in response to $2 \mathrm{ppm}$ and $4 \mathrm{ppm} \mathrm{MC}$, respectively, but decreased to 2.09 fold and 0.97 fold in response to $6 \mathrm{ppm} \mathrm{MC}$, respectively than 3.12 fold and 1.94 fold of control, respectively. With the substrate EPNP, GST specific activity was increased 0.98 fold and 1.96 folds in response $2 \mathrm{ppm}$ and $4 \mathrm{ppm} \mathrm{MC}$, respectively, but decreased to 0.81 fold in response to $6 \mathrm{ppm} \mathrm{MC}$ than 1.83 fold of control. With the substrate p-NPA, GST specific activity was increased to 1.38 fold and 3.34 fold in response to $2 \mathrm{ppm}$ and $4 \mathrm{ppm} \mathrm{MC}$, respectively, but decreased to 3.21 fold in response to $6 \mathrm{ppm} \mathrm{MC}$ than 4.85 fold of control. With the substrate CHP, GST specific activity was increased to 1.31 fold and 2.68 fold in response to $2 \mathrm{ppm}$ and $4 \mathrm{ppm} \mathrm{MC}$, respectively, but decreased to 2.09 fold in response to $6 \mathrm{ppm} \mathrm{MC}$ than 3.3 fold of control.

Table 3: Effect of MC on chick embryo brain GSTs by 48 hours interval.

\begin{tabular}{ccccc}
\hline M.S & Control & $\mathbf{2} \mathbf{p p m}$ & $\mathbf{4} \mathbf{~ p m}$ & $\mathbf{6} \mathbf{~ p m}$ \\
\hline CDNB & $0.656 \pm 0.016$ & $0.815^{\mathrm{a}} \pm 0.015$ & $0.945^{\mathrm{a}} \pm 0.015$ & $0.194^{\mathrm{a}} \pm 0.017$ \\
BSP & $0.312 \pm 0.012$ & $0.478^{\mathrm{a}} \pm 0.014$ & $0.685^{\mathrm{a}} \pm 0.015$ & $0.103^{\mathrm{a}} \pm 0.015$ \\
pNBC & $0.194 \pm 0.014$ & $0.309^{\mathrm{a}} \pm 0.015$ & $0.401^{\mathrm{a}} \pm 0.017$ & $0.097^{\mathrm{a}} \pm 0.016$ \\
EPNP & $0.183 \pm 0.013$ & $0.281^{\mathrm{a}} \pm 0.016$ & $0.379^{\mathrm{a}} \pm 0.019$ & $0.102^{\mathrm{a}} \pm 0.019$ \\
PNPA & $0.485 \pm 0.015$ & $0.623^{\mathrm{a}} \pm 0.013$ & $0.819^{\mathrm{a}} \pm 0.018$ & $0.164^{\mathrm{a}} \pm 0.014$ \\
CHP & $0.330 \pm 0.010$ & $0.461^{\mathrm{a}} \pm 0.017$ & $0.598^{\mathrm{a}} \pm 0.017$ & $0.121^{\mathrm{a}} \pm 0.017$ \\
\hline
\end{tabular}

The documented values are average of three separate experiments of three samples. Mean \pm standard deviation (SD). Student test $(\mathrm{a}=\mathrm{p}<0.05$ is regarded as significant specific activity of GST). Doubling the dose 2 ppm MC per day for chick embryos by 48 hours interval. 1 unit of GST activity is defined as $1 \mu$ mole of GSH conjugate formed/min/mg protein (CDNB, BSP, pNBC, EPNP, pNPA), $1 \mathrm{n}$ mole of NADPH oxidised/min/mg protein (CHP).

\section{Western blot analysis}

As shown in Figure 3, in twenty four hours interval, GST expression levels were significantly increased in response to $2 \mathrm{ppm} \mathrm{MC}$ and $4 \mathrm{ppm} \mathrm{MC}$, but GST expression levels were decreased in response to $6 \mathrm{ppm}$ MC. Similarly, in forty eight hours interval, GST expression levels were significantly increased in response to 2 ppm MC and 4 ppm MC, but GST expression levels were decreased in response to $6 \mathrm{ppm}$. Initially, GST expression was activated when MC entered in to cell, but excess infiltration of MC lead to deactivation of GST expression.

\section{Developing chick embryo brain injury by MC}

As shown in Figure 4, control cerebellum molecular layer, granular layer; Purkinje cell layer with in granular layer and white matter between two granular layers were noticed. As shown in Figure $5 \& 6,6 \mathrm{ppm}$ MC administered section were injured in both intervals. In 24 hours interval, 6 ppm MC administered brain section cerebellar layers degeneration, expansion of molecular layer towards granular layer and vacuolation were noticed as shown in Figure 5. In 48 hours interval, 6 ppm MC administered brain section severe cerebral haemorrhages and vacuolation was noticed as shown Figure 6.

In the present study, expressed brain GST isoenzymes by the administration of MC were screened by using model substrates such as CDNB, BSP, pNBC, EPNP, pNPA and CHP as shown in
Table $2 \& 3$, Figure $1 \mathrm{~A} \& 1 \mathrm{~B}$, Figure 2A \& 2B.
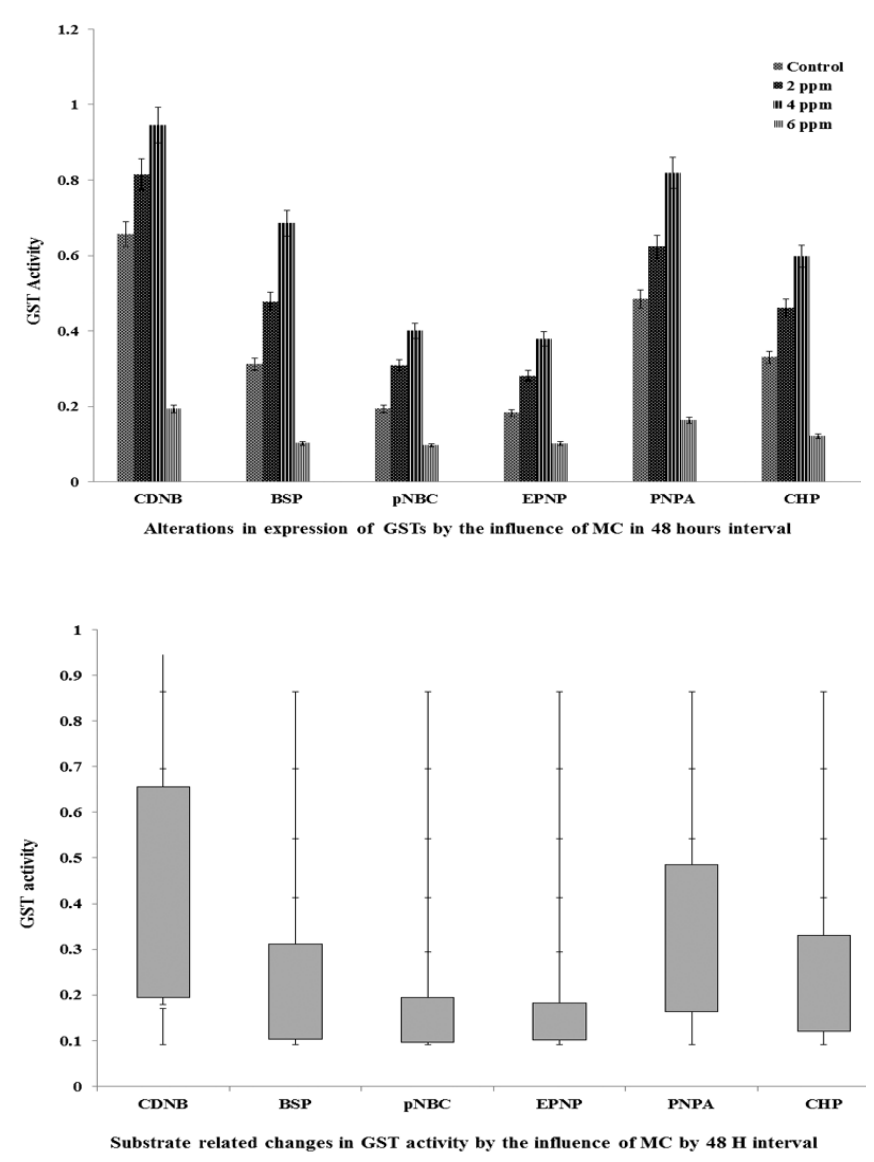

Fig. 2: (A) Expression levels of brain GSTs in response to MC by 48 hours interval. (B) MC administered brain GSTs specific activity with model substrates by 48 hours interval.

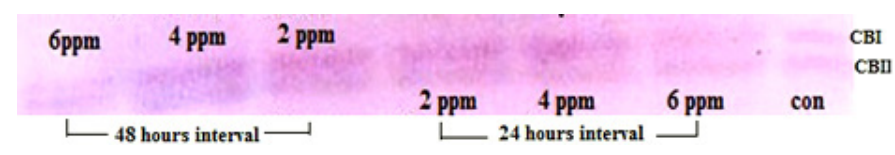

Fig. 3: Western blot of chick embryo brain GSTs expressed by MC.

As shown in Table 2 \& 3, Figure 1A \& 1B, Figure 2A \& $2 \mathrm{~B}$, with the substrate CDNB, GST specific activity was increased to 2.7 fold $\& 4.49$ fold by 24 hours interval and 1.59 fold \& 2.89 fold by 48 hours interval, in response to $2 \mathrm{ppm} \mathrm{MC} \mathrm{and} 4$ ppm MC. Henceforth, the specific activity was decreased to 2.53 fold by 24 hours interval and 4.62 fold by 48 hours interval, in response to 6 ppm MC than 4.25 fold and 6.56 fold of control in both intervals, respectively.

As shown in Table $2 \&$ 3, Figure $1 \mathrm{~A} \&$ 1B, Figure $2 \mathrm{~A}$ $\& 2 \mathrm{~B}$, with the substrates BSP and pNBC, GST specific activities were increased to 1.52 fold \& 1.15 fold as well as 2.5 fold \& 2.19 fold by 24 hours interval and 1.66 fold \& 1.15 fold as well as 3.73 fold \& 2.07 fold by 48 hours interval in response to $2 \mathrm{ppm}$ $\mathrm{MC}$ and $4 \mathrm{ppm} \mathrm{MC}$, respectively. Henceforth, the specific activity was decreased to 1.42 fold \& 0.64 fold by 24 hours interval and 2.09 fold \& 0.97 fold by 48 hours interval, in response to 6 
ppm MC than 2.13 fold and 1.55 fold of control for 24 intervals, respectively, as well as 3.12 fold and 1.94 fold of control for 48 hours interval, respectively.

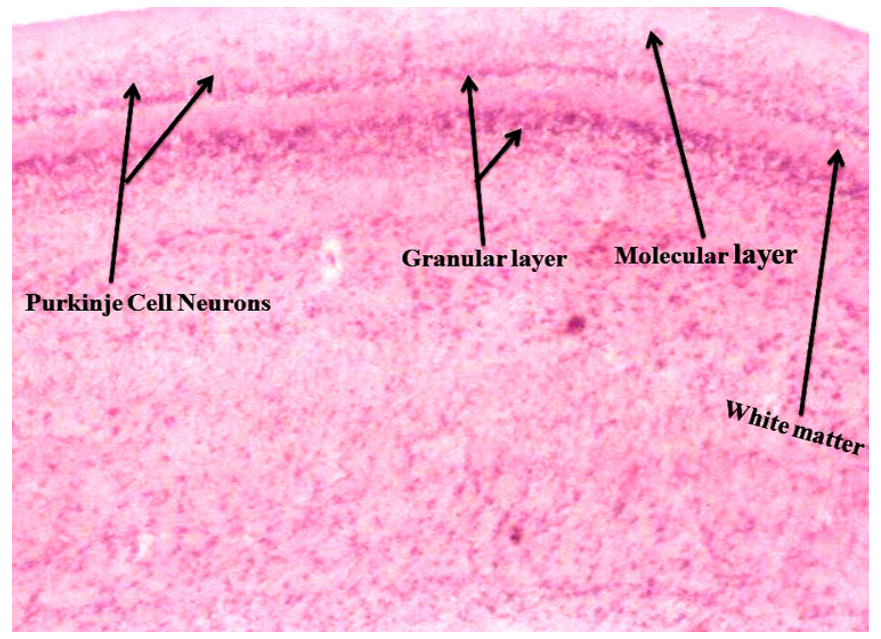

Fig. 4: Control cerebellum section showing molecular layer, granular layer, Purkinje cell neurons and white matter (H \& E stain) (20X).

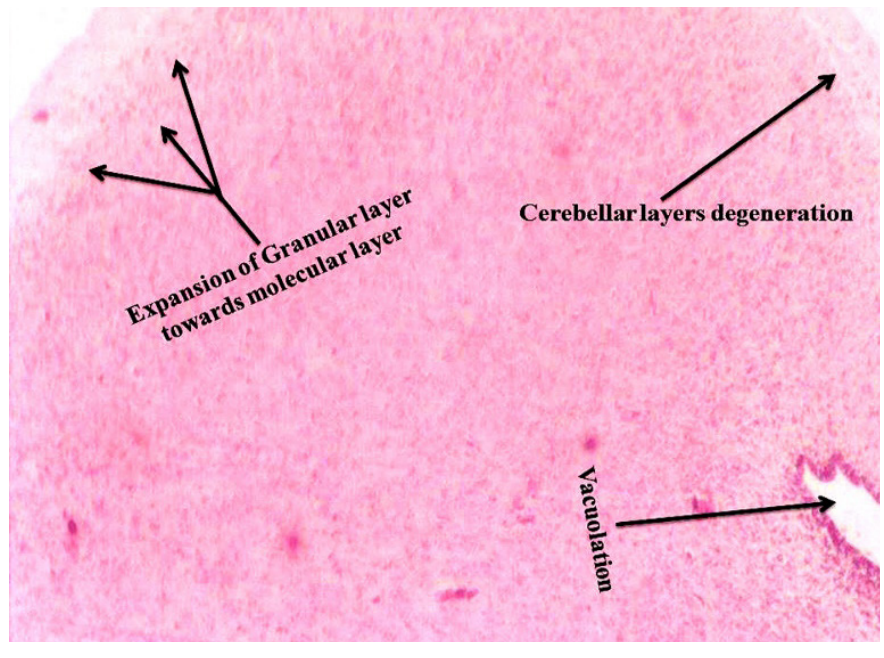

Fig. 5: 6 ppm MC administered chick embryo section shows cerebellar layers degeneration, expansion of granular layer towards molecular and vacuolation by 24 hours interval (H \& E stain) (20X).

As shown in Table $2 \& 3$, Figure $1 \mathrm{~A} \&$ 1B, Figure $2 \mathrm{~A} \&$ $2 \mathrm{~B}$, with the substrate EPNP, GST specific activity was increased to 1.26 fold $\& 2.51$ fold by 24 hours interval and 0.98 fold $\& 1.96$ fold by 48 hours interval, in response 2 ppm MC and 4 ppm MC, respectively. Henceforth, the specific activity was decreased to 0.56 fold by 24 hours interval and 0.81 fold by 48 hours interval, in response to $6 \mathrm{ppm} \mathrm{MC}$ than 1.45 fold and 1.83 fold of control in both intervals, respectively.

As shown in Table $2 \& 3$, Figure $1 \mathrm{~A} \& 1 \mathrm{~B}$, Figure $2 \mathrm{~A} \&$ $2 \mathrm{~B}$, with the substrate pNPA, GST specific activity was increased to 2.6 fold \& 4.56 fold by 24 hours interval and 1.38 fold \& 3.34 fold by 48 hours interval, in response to $2 \mathrm{ppm} \mathrm{MC}$ and $4 \mathrm{ppm}$ MC. Henceforth, the specific activity was decreased to 2.13 fold by 24 hours interval and 3.21 fold by 48 hours interval in response to $6 \mathrm{ppm} \mathrm{MC}$, respectively than 3.25 fold and 4.85 fold of control in both intervals, respectively.

As shown in Table $2 \& 3$, Figure $1 \mathrm{~A} \& 1 \mathrm{~B}$, Figure $2 \mathrm{~A} \&$ $2 \mathrm{~B}$, with the substrate CHP, GST specific activity was increased 1.01 fold $\& 1.46$ fold by 24 hours interval and 1.31 fold $\& 2.68$ fold by 48 hours interval in response to $2 \mathrm{ppm} \mathrm{MC}$ and $4 \mathrm{ppm} \mathrm{MC}$. Hence forth the specific activity was decreased to 1.29 fold by 24 hours interval and 2.09 fold by 48 hours interval in response to 6 ppm $\mathrm{MC}$ respectively, than 2.3 fold and 3.3 fold of control, in both intervals, respectively.

Mannervik and Jensson (1982) said that the mu ( $\mu$ ) GST catalyse the GSH conjugation with BSP as well as CDNB. Mu $(\mu)$ class GST has highest specific activity with the substrate CDNB (Contreras-Vergara et al., 2007). Hayes and Pulford (1995) said that, mu $(\mu)$ GST has shown significant activity with pNBC and EPNP. As shown in Table $2 \& 3$, Figure 1A \& 1B, Figure 2A \& 2B, chick embryo brain GSTs specific activity with BSP, pNBC and EPNP including CDNB have shown existence of $\mu$ GST. So, present study was agreed with Mannervik and Jensson (1982), Hayes and Pulford (1995), Contreras-Vergara et al. (2007).

Mannervik et al. (1988) said that, a substrate of specific class GST can show activity with other class GST. Mu $(\mu)$ GST activity was enhanced with pNPA and EPNP than genetic variants (Kurtovic et al., 2007). Wild type alpha ( $\alpha$ ) GST activity was increased with pNPA and CHP (Zhang et al., 2012). Mclellan et al. (1992) and Mitchell et al. (1997) were said that the alpha $(\alpha)$ and $\mathrm{mu}(\mu)$ GSTs are present in brain and other organs. Dasari et al. (2016) reported based on purification studies and substrate specific reaction studies, $\mathrm{CB}_{\mathrm{I}}$ \& $\mathrm{CB}_{\mathrm{II}}$ GSTs of chick embryo brain have similarity with alpha $(\alpha)$ and $\mathrm{mu}(\mu)$ class GSTs. As shown in Table $2 \& 3$, Figure 1A \& 1B, Figure 2A \& 2B, chick embryo brain GSTs specific activity with pNPA was show the existence of alpha $(\alpha)$ and mu $(\mu)$ class GSTs. Therefore the present study was agreed with Mannervik and Danielson (1988), Kurtovik et al. (2007), Zhang et al., (2012), Mclellan et al. (1992), Mitchell et al. (1997), Dasari et al. (2016).

Mannervik et al. (1985) said that the alpha $(\alpha)$ class GST activity towards CHP, represents the selenium independent glutathione peroxidase activity. Chang et al. (1990), said that the physiological role of non-selinium GPx activity is associated with the GSTs is very interesting. Among GST enzymes that the alpha $(\alpha)$ can actively protect cells from lipid hydroperoxides which generated by oxidative stress (Spector et al., 2000). That the turkey alpha GSTs which have highest catalytic activity towards CDNB and CHP (Kim et al., 2011). Yang et al. (2001) said that the alpha GST can perform large part of peroxidase activity and this kind of activity is necessary part of defense mechanism of cell. As shown in Table $2 \& 3$, Figure $1 \mathrm{~A} \& 1 \mathrm{~B}$, Figure 2A \& 2B, chick embryo brain GSTs activity with CHP was show the existence of $\alpha$ GST and its non-selenium GPx activity. Therefore the present study was agreed with Mannervik (1985), Chang et al. (1990), Spector et al. (2000), Kim et al. (2011) and Yang et al. (2001).

As shown in Table $2 \&$ 3, Figure $1 \mathrm{~A} \&$ 1B, Figure 2A $\& 2 \mathrm{~B}$, it was observed that the GST activity was increased by 24 hours interval and 48 hours interval, in response to $2 \mathrm{ppm} \mathrm{MC}$ and $4 \mathrm{ppm} \mathrm{MC}$, respectively. This may be due to increased process of detoxification. As in Figure 3, immunoblot with primary antibody that specific to chick embryo brain GSTs, showed band pattern similar to purified GST band pattern $\left(\mathrm{CB}_{\mathrm{I}}\right.$ and $\mathrm{CB}_{\mathrm{II}}$, our 
published work) and it was observed that the increased levels of GST expression in response to $2 \mathrm{ppm} \mathrm{MC}$ and $4 \mathrm{ppm} \mathrm{MC}$, it may be due to increased process of detoxification. As shown in Table $2 \& 3$, Figure $1 \mathrm{~A} \& 1 \mathrm{~B}$, Figure $2 \mathrm{~A} \& 2 \mathrm{~B}$, it was observed that the GST activity decreased in both intervals, in response to $6 \mathrm{ppm}$. This may be due to suppression of GST by excess infiltration of MC. Similarly as shown in Figure 3, it was observed that the decreased levels of GST expression in response to $6 \mathrm{ppm} \mathrm{MC} \mathrm{in}$ both intervals, this may be due to suppression of GST expression by MC. GST activity increased when expression of GST increased hence detoxification process increases, but GST activity decreased when expression of GST supressed because of excess accumulation toxic chemical agents (Dasari et al., 2018). In this study, we observed the similar results.



Fig. 6: 6 ppm $\mathrm{MC}$ administered chick embryo section shows cerebellar haemorrhage and vacuolation by 48 hours interval (H \& E stain) (20X).

Through histopathology study, as shown in Figure 4 , in chick embryo control cerebellum section has three intact layers. But MC treated cerebellum sections were injured severely as shown in Figure $5 \& 6$, in both intervals. PAHs are shows moderate to high acute toxicity to birds and aquatic beings (Abdel-Shafy et al., 2016). PAHs interact with brain tissue (Tayebati et al., 2009). GST specific isoform variation can help in deeper view of histopathological conditions (Acharjee and Mahanta, 2014). Significant level expression of alpha GST is a signal for more complex damage (Giannini et al., 2001). Mu GSTs play a key role in neuroprotection (Dagnino-Subiabre et al., 2000). As shown in the Figure 5 \& Figure 6, MC administered chick embryo brain tissue was seriously injured. So, the present study was agreed with Abdel-Safy et al. (2016), Tayebati et al. (2009), Acharjee and Mahanta, (2014), Giannini et al. (2001) and Dagnino-Subiare et al. (2000).

\section{CONCLUSION}

GST isoenzymes expressed by the administration of $\mathrm{MC}$, showed significant specific activity with the model substrates like BSP, p-NBC, p-NPA and CHP including CDNB. GSTs specific activity with substrates BSP and pNBC showed the existence of $\mu$ GST; with substrate p-NPA showed the existence of $\alpha$ and $\mu$ GSTs. GSTs specific activity with the substrate CHP showed the existence of GST associated peroxidase activity. Continues infiltration of MC into brain may supress the expression GST and ultimately made brain injury. Key conclusion, both specific activity and western blot studies proved that $\mathrm{MC}$ is a potent neurotoxic chemical compound, that supress chick embryo brain $\mathrm{CB}_{\mathrm{I}}$ and $\mathrm{CB}_{\mathrm{II}}$ ) GSTs and made brain degeneration.

\section{ACKNOWLEDGMENTS}

Authors are grateful to the University Grants Commission (UGC), New Delhi, India who given generous financial assistance as JRF and SRF (ROC. No.20601/UGC-1/2/RGNF/2007).

\section{CONFLICT OF INTEREST}

Authors do not have any potential conflict of interest.

\section{REFERENCES}

Abdel-Shafy HI, Mansour MS. A review on polycyclic aromatic hydrocarbons: source, environmental impact, effect on human health and remediation. Egyptian J Petroleum, 2016; 25:107-23.

Acharjee BK, Mahanta R. Induction of Non-Cytochrome Mediated Enzymes-Xanthine Oxidase and Glutathione-S-Transferase By 3-Methylcholanthrene in Kidney Tissues of Male Albino Mice. Asian J Biomed Pharmaceut Sci, 2014; 4: 11-16.

Akyuz M, Cabuk H. Gas-particle partitioning and seasonal variation of polycyclic aromatic hydrocarbons in the atmosphere of Zonguldak, Turkey. Sci Total Environ, 2010; 408:5550-58.

Arakawa S. Utilization of glutathione S-transferase $\mathrm{Mu}$ 1- and Theta 1-null mice as animal models for absorption, distribution, metabolism, excretion and toxicity studies. Expert Opin Drug Metab Toxicol, 2013; 9: 725-36.

Armstrong B, Hutchinson E, Unwin J, Fletcher T. Lung Cancer Risk after Exposure to Polycyclic Aromatic Hydrocarbons: A Review and Meta-Analysis. Environ Health Perspect, 2004; 112: 970-78.

Ates NA, Tamer L, Ates C, Ercan B, Elipek T, Ocal K et al. GST M1, T1, P1 genotypes and risk for development of colorectal cancer. Biochem Genet, 1995; 43: 149-63.

Batty GD, Der G, Deary IJ. Effect of maternal smoking during pregnancy on offspring's cognitive ability: Empirical evidence for complete confounding in the US national longitudinal survey of youth. Pediatrics, 2006; 118: 943-50.

Bal-Price AK, Hogberg HT, Buzanska L, Lenas P, van Vliet E, Hartung T. In vitro developmental neurotoxicity (DNT) testing: Relevant models and endpoints. Neurotoxicol, 2010; 31: 545-54.

Chang M, Burgess JR, Scholz RW, Reddy CC. The induction of specific rat liver glutathione $\mathrm{S}$-transferase subunits under inadequate selenium nutrition causes an increase in prostaglandin F2 alpha formation. J Biol Chem, 1990 265: 5418-23.

Contreras-Vergara CA, Valenzuela-Soto E, García-Orozco KD, Sotelo-Mundo RR, Yepiz-Plascencia G. A Mu-class glutathione S-transferase from gills of the marine shrimp Litopenaeus vannamei: Purification and characterization. J Biochem Mol Toxicol, 2007; 21: $62-7$.

Dagnino-Subiabre A, Cassels BK, Baez S, Johansson AS, Mannervik B, Segura-Aguilar J. Glutathione transferase M2-2 catalyzes conjugation of dopamine and dopa o-quinones. Biochem Biophys Res Commun, 2000; 274:32-6.

Dasari S, Gonuguntla S, Ganjayi M, Meriga B, Kedam T. Biochemical characterization of glutathione S-transferases purified from chick embryo brain. Journal of Animal and Poultry Sciences, 2016; 5: 4251.

Dasari S, Ganjayi MS, Oruganti L, Balaji H, Meriga B. Glutathione S-transferases Detoxify Endogenous and Exogenous Toxic Agents-Minireview. J Dairy Vet Anim Res, 2017a; 5: 1-3

Dasari S, Ganjayi MS, Meriga B. Bird glutathione s-transferases: endogenous and exogenous toxic insults. Adv Anim Vet Sci, 2017b; 5: 38894. 
Dasari S, Ganjayi MS, Meriga B, Kedam T. Developmental neurotoxicity of acrylamide: defensive role of chick embryo glutathione s-trans-ferases. Adv Anim Vet Sci, 2017c; 5: 299-306.

Dasari S, Gonuguntla S, Meriga B, Kedam T, Determination of acrylamide-induced chick embryo brain glutathione S-transferases expression through enzyme activity and western blot. J Appl Biol Biotechnol, 2018; 6: 43-7.

Di Toro DM, McGrath JA, Hansen DJ. Technical basis for narcotic chemicals and polycyclic aromatic hydrocarbon criteria. I. Water and tissue. Environ Toxicol Chem, 2000;19: 1951-70.

Giannini E, Mastracci L, Botta F, Romagnoli P, Fasoli A, Risso D, Faravelli F, Ceppa P, Lantieri PB, Icardi GC, Testa R. Liver iron accumulation in chronic hepatitis $\mathrm{C}$ patients without HFE mutations: relationships with histological damage, viral load and genotype and $\alpha$-glutathione S-transferase levels. Eur J Gastr Hepatol, 2001; 13:1355-61.

Grandjean P, Landrigan PJ. Developmental neurotoxicity of industrial chemicals. The Lancet, 2006; 368: 2167-78.

Habig WH, Pabst MJ, Jakoby WB. Glutathione S-transferases the first enzymatic step in mercapturic acid formation. J Biol Chem, 1974; 249: 7130-9.

Hayes JD, Pulford DJ. The glut athione S-transferase supergene family: regulation of GST and the contribution of the 1soenzymes to cancer chemoprotection and drug resistance part II. Crit Rev Biochem Mol Biol, 1995; 30: 521-600.

Humason GL. 1972. Specific staining methods. Animal tissue techniques. San Francisco, CA: WH Freeman and Co.

Jakoby WB, Habig WH. 1980. Glutathione S-transferases. Enzymatic basis of detoxification. Vol II. New York: Academic Press.

Kaminski E, Kaplan BF, M.P. Holsapple MP. 2008. Toxic responses of the immune system. In: Klassen CD, ed. Casarett and Doulle"s Toxicology: The Basic Science of Poisons. New York: McGraw-Hill Medical Publishing Division 485-556.

Kim JE, Bunderson BR, Croasdell A, Coulombe Jr RA. Functional characterization of alpha-class glutathione S-transferases from the turkey (Meleagris gallopavo). Toxicol Sci, 2011; 124: 45-53.

Kurtovic S, Runarsdottir A, Emrén LO, Larsson AK, Mannervik B. Multivariate-activity mining for molecular quasi-species in a glutathione transferase mutant library. Protein Eng Des Sel, 2007; 20: 243-56.

Laemmli UK. Cleavage of structural proteins during the assembly of the head of bacteriophage T4. Nature, 1970; 227 (5259): 68085.

Lannerö E, Wickman M, van Hage M, Bergström A, Pershagen G, Nordvall L. Exposure to environmental tobacco smoke and sensitisation in children. Thorax, 2008; 63: 172-6.

Li T, Zhao XP, Wang LY, Gao S, Zhao J, Fan YC, Wang K. Glutathione S-transferase P1 correlated with oxidative stress in hepatocellular carcinoma. Int J Med Sci, 2013; 10: 683-90.

Liu J, Li J, Liu Y, Chan HM, Zhao Y, Cai Z et al. Comparison on gestation and lactation exposure of perfluorinated compounds for newborns. Environ Int, 2011; 37: 1206-12.

Lowry OH, Rosebrough NJ, Farr AL, Randall RJ. Protein measurement with the Folin phenol reagent. J Biol Chem, 1951; 193: $265-$ 75 .

Mannervik B, Jensson H. Binary combinations of four protein subunits with different catalytic specificities explain the relationship between six basic glutathione S-transferases in rat liver cytosol. J Biol Chem, 1982; 257: 9909-12.

Mannervik B, Danielson UH, Ketterer B. Glutathione transferases - structure and catalytic activity. Crit Rev Biochem, 1988; 23 : 283-337.

Mannervik B, Alin P, Guthenberg C, Jensson H, Tahir MK, Warholm $\mathrm{M}$ et al. Identification of three classes of cytosolic glutathione transferase common to several mammalian species: correlation between structural data and enzymatic properties. Proc Natl Acad Sci. 1985; 82: 7202-206

McLellan LI, Harrison DJ, Hayes JD. Modulation of glutathione
S-transferases and glutathione peroxidase by the anticarcinogen butylated hydroxyanisole in murine extrahepatic organs. Carcinogenesis, 1992;13: 2255-61.

Mitchell AE, Morin D, Lakritz J, Jones AD. Quantitative profiling of tissue-and gender-related expression of glutathione S-transferase isoenzymes in the mouse. Biochem J, 1997 325: 207-16.

Nielsen JK, Vikström AC, Turner P, Knudsen LE. Deoxynivalenol transport across the human placental barrier. Food Chem Toxicol, 2011;49: 2046-52.

O'Donnell EP, Zerbe LK, Dwyer-Nield LD, Kisley LR, Malkinson AM. Quantitative analysis of early chemically-induced pulmonary lesions in mice of varying susceptibilities to lung tumorigenesis. Cancer lett, 2006; 24:197-202.

Omiecinski CJ, Vanden Heuvel JP, Perdew GH, Peters JM. Xenobiotic metabolism, disposition, and regulation by receptors: from biochemical phenomenon to predictors of major toxicities. Toxicol Sci, 2010; 120: S49-75.

Perera FP, Chang HW, Tang D, Roen EL, Herbstman J, Margolis A et al. Early-life exposure to polycyclic aromatic hydrocarbons and ADHD behavior problems. PLoS One, 2014; 9:e111670.

Polanska K, Hanke W, Sobala W, Brzeznicki S, Ligocka D. Exposure of smoking pregnant women to polycyclic aromatic hydrocarbons. Medycyna pracy. 2009; 60:103-8.

Rodgman A, Smith CJ, Perfetti TA. The composition of cigarette smoke: a retrospective, with emphasis on polycyclic components. Hum Exp Toxicol, 2000; 19: 573-95.

Salinas AE, Wong MG. Glutathione S-transferases-a review. Curr Med Chem, 1999; 6: 279-310.

Singh AK, Kashyap MP, Kumar V, Tripathi VK, Yadav DK, Khan $\mathrm{F}$ et al. 3-Methylcholanthrene induces neurotoxicity in developing neurons derived from human CD34+ Thy $1+$ stem cells by activation of aryl hydrocarbon receptor. Neuromol Med, 2013; 15: 570-92.

Speer K, Steeg E, Horstmann P, Kühn T, Montag A. Determination and distribution of polycyclic aromatic hydrocarbons in native vegetable oils, smoked fish products, mussels and oysters, and bream from the river Elbe. J Sep Sci, 1990;13:104-11.

Spector A, Wang RR, Ma W, Kleiman NJ. Development and characterization of an $\mathrm{H} 2 \mathrm{O} 2$-resistant immortal lens epithelial cell line. Invest Ophthalmol Vis Sci, 2000; 41: 832-43.

Strange RC, Fryer AA. The glutathione S-transferases: influence of polymorphism on cancer susceptibility. IARC Sci Publ, 1999; 148: 23149.

Tayebati SK, Di Tullio MA, Ricci A, Amenta F. Influence of dermal exposure to the pyrethroid insecticide deltamethrin on rat brain microanatomy and cholinergic/dopaminergic neurochemistry. Brain Res, 2009; 1301: 180-8.

Thapar A, Fowler T, Rice F, Scourfield J, van den Bree M, Thomas $\mathrm{H}$ et al. Maternal smoking during pregnancy and attention deficit hyperactivity disorder symptoms in offspring. Am J Psychiatry, 2003; 160: 1985-9.

Tilson HA. Neurotoxicology risk assessment guidelines: developmental neurotoxicology. Neurotoxicol, 2000; 21:189-94.

Towbin H, Staehelin T, Gordon J. Electrophoretic transfer of proteins from polyacrylamide gels to nitrocellulose sheets: procedure and some applications. 1979. Biotechnology (Reading, Mass.), 1992; 24:14549.

Voso MT, Hohaus ST, Guidi F, Fabiani E, D'Alò FR, Groner S et al. Prognostic role of glutathione S-transferase polymorphisms in acute myeloid leukemia. Leukemia. 2008; 22: 1685-91.

Wendel A. Glutathione peroxidase. Methods Enzymol. 1981; 77 325-33.

Yang Y, Cheng JZ, Singhal SS, Saini M, Pandya U, Awasthi S et al. Role of glutathione S-transferases in protection against lipid peroxidation overexpression of HGSTA2-2 in K562 cells protects against hydrogen peroxide-induced apoptosis and inhibits JNK and caspase 3 activation. J Biol Chem, 2001; 276: 19220-30. 
Zhang W, Dourado DF, Fernandes PA, Ramos MJ, Mannervik B. Multidimensional epistasis and fitness landscapes in enzyme evolution. Biochem J, 2012; 445: 39-46.

How to cite this article:

Dasari S, Gonuguntla S, Meriga B, Kedam T. Adverse influence of $\beta$-methylcholanthrene on detoxification function of chick embryo brain glutathione S-transferases and degenerative changes of brain. J App Pharm Sci, 2018; 8(03): 111-119. 